\title{
Batak Women in Surabaya between Globalization and Local Policies
}

\author{
Sherly Deasy Anjuwita Gultom \\ Magister Sosiologi, FISIP, UNAIR \\ Surabaya, Indonesia \\ sherly_deasy.gloria@yahoo.com
}

\begin{abstract}
The existence of local policies are not separated from the role of women as a factor supporting the policy itself. The modern era of globalization affect the continuities and changes in each line of the local policy. Batak as one ethnic uphold local policies come adapt to the pattern of globalization that inevitably should be followed in order to attain an existence in a culture. Women as one of the media that bridge any cultural elements on nxt generation must participate and adapt to globalization. Changes and adjustments that occurred in the socialization process carried out by women in maintaining local cultural identity was primarily aimed at maintaining the culture itself and the status of bears.
\end{abstract}

Keywords—globalization, local policies, woman, adaptation, alteration, Batak

\section{INTRODUCTION}

Modernization as a major factor in the globalization process has a very big role in the development and dissemination. The development of information and communication technology as a sub-factor in the modernization of societies and individuals facilitate any access to various information in every respect, time and place that is not accessible to physical limitations. Globalization forces us quickly whether or not to compete in reaching a leading value. Modernization, globalization, technological developments and communication is closely related to one another that can not be separate

In this concept is not wrong when we ultimately judge globalization as a disaster that can diminish the policy of local cultural policies have on the community. Globalization is closely associated with the western culture or in developed countries which is actually a state - western countries. Globalization is consciously unaware of disseminating the value of Western culture to other developing countries that only received the impact of globalization itself.

Mastery of technology and communication as a major factor supporting the globalization of the western world, erode the value of local culture which is owned by the developing countries. Developing countries in the era of globalization is still at the level of "recipient" alone of all the impacts posed by globalization itself. Indonesia as one of the developing countries that run and receive the effects of globalization consciously or not has a lot of parts of the culture and local policies are gradually eroded by the current. Patron of western culture in the era of globalization is not only limited to the western world as a limitation "territory". Country - East Asian countries like Japan and
Korea are regarded as developed countries that can compete with the state - western world countries is also a separate vote in eroding the value of the local culture. Pop culture, $\mathrm{K}$-pop increasingly in demand by people in Indonesia are considered more modern and contemporary. Conventional culture that emphasizes courtesy, tolerance, respect for someone older and togetherness was no longer considered to be something of value compared with the pretext of freedom of expression, work, self-recognition and achievement. The biggest problem, according to Saidi (1998), has been going a long time since the start of the era of liberalism in Indonesia during the Soeharto. During the liberals, culture foreign culture into Indonesia in line with the influence

The family as one of the smallest unit of society, has a very large function in maintaining the existence of the local culture in the era of globalization. One function of the family according to Friedman (1998) as a function of socialization. Mother as stakeholders in the process of socialization of value that is very influential on the socialization process. Women who are identified within the household sector are not inferior to men who have authority in the public sphere. Values in the domestic sphere will undergo a change when the socialization agents receive value - different values or even just from the outside world. The intepretation of the value that will be socialited by women will hane an impact on its own the existing local culture.

Thus one of the biggest challenges in this era, interms of local culture is to maintain a self-run existence of a smallest unit of a family. Women as agents of socialization in the family has its own strategies to maintain the existence of the local culture in the era of globalization.

In reviewing the above issues, researchers will use a qualitative method with phenomenological approach which will be based on critical theory. The data used in analyzing the problems above are primary data recieved directly by researchers from the field by using the method of participant observation and in-depth interviews. As supporting data, researchers will use primary data from an existing library materials.

The setting is set in Surabaya, in consideration as one of the metropolis in Indonesia, wich is one of the most favourable city to urbanite for the Batak ethnicity.

\section{RESEARCH METHOD}

This research used a qualitative method which a field activitias such observation, informal discussion and in-depth interview were done. The location was in Surabaya in which 
the Bataknese community live. All the interview with the informants were recorded as the main data. Some documentary data also supported the analysis of the research.

\section{ReseArCh Result: Woman, CULture AND GLOBALIZATION}

According to Jan Aart Scholte (2001) the process of globalization through five key indicators are: internationalization, westernization, economic liberalization. Democratization, and deterritorialized. From one of the above indicators of westernization is a form of diffusion values of western culture into value - local value, which in turn erodes the value of the local culture itself. Approximately $80 \%$ of the world colonized by the west, it is conscious or not will form its own mindset for the world that culture or civilization that brought or possessed by Western countries is a culture with a very high civilization values. Feasibility of western culture to be emulated by other countries both in every field related to the concept of modernity, have legalized its own for every individual who subscribes.

The local culture is a policy or wisdom possessed by a nation. The local culture is a reflection of the deal - as well as the rules, values and norms born of adjustment of the state of a society in facing the challenges of his life.

The status of women will only be limited to the fulfillment of a demand within a community, due to a view that women do not yet eligible for a line of creativity, intellect and extensive knowledge competition process a work ethic. In this case a lot of people view what we often call up as a patrilineal pattern ironically supported by the women themselves.

Globalization as a driver of competitive attitude and openness inadvertently provide opportunities for women who are principled "modern" to be able to break the pattern of expression over the patrilinialisme that limit their creativity. What about the local policies that exist in the world ?. Women who are limited houshold, have a very important role in the process of extension of a culture.

Married woman or a mother will always have an understanding that the development of the child, the child's success will be determined from the hands of a mother. A mother is the most viable figure in the process of formation of a person's character or success. From this understanding emerged the idea that women become one of the status and role is very important to consider its existence. A wide variety of women's empowerment programs created to improve the quality of a woman's own resources.

The fade of the value of local culture or local wisdom of globalization, is closely related to the socialization process in the family. Globalization is blurring the boundaries that diverse traditional business, media and education, restructure the business, encouraging reinterpretation of trade and investment, health, entertainment, government, work patterns, trade, production patterns, even patterns of relationship between communities and between individuals. This is concentrated in a challenge for all nations, communities and individuals around the world (Justiani 2009).

In the era of globalization revolutionized $4 \quad \mathrm{~T}$ (Technology, Telecommunications, Transportation, Tourism) which has a dominant force thus globalizing between region will limit increasingly unclear and led to global village as it had been predicted McLuhan (Saptadi 2008).

Local culture will be fade such as the style of dress, which at present is considered that the community feels mini dress more beautiful than the garment closed. Language diarasa less fit their area or even feel more "rustic" than the use of foreign languages which are considered more dignified or civilized. Things - like this that encourages the woman to keep the existence of the local culture of scour scouring pattern of globalization that all of them it would not be appropriate and be true to our own culture.

Emotionally women sometimes tend to be possessive in addressing an issue so the role of men is also needed as a counterweight. However, the presence of women is a new force. Women can adapt to the environment in its broadest sense is of significant importance in the life of a man with a good, active and selective.

\section{REFERENCES}

[1] Justiani, (Globalization and Indonesian Nationalism) "Globalisasi dan Nasionalisme Indonesia”, Surabaya Post, 27 April 2009.

[2] Saidi. R, (Culture in the Monetary Crisis, Indonesia in A Transition) "Kebudayaan di Zaman Krisis Moneter Dalam Indonesia di Simpang Jalan," Bandung: Mizan, 1998.

[3] Saptadi. KY, (Reading Globaliation in the Frame of Cultural War) "Membaca Globalisasi dalam Kaca Mata Perang Budaya", A Paper of Globalization Seminar "Seni, dan Moral Bangsa" at Indonesia Research Instite (LIPI). Jakarta, 25 Maret, 2008. 